American Journal of Applied Sciences 9 (7): 1046-1054, 2012

ISSN 1546-9239

(C) 2012 Science Publications

\title{
Simplified Modeling, Analysis and Simulation of Permanent Magnet Brushless Direct Current Motors for Sensorless Operation
}

\author{
Kaliappan, E. and C. Chellamuthu \\ Department of Electrical and Electronics Engineering, \\ RMK Engineering College, Kavaraipettai, Chennai-601206, India
}

\begin{abstract}
Problem statement: In this study, a simplified modeling and experimental analysis of Permanent Magnet Brushless DC (PMBLDC) motors for Sensorless operation using MATLAB/SIMULINK. This model provides a mechanism for monitoring and controlling the voltage, current, speed and torque response. Approach: BLDC motor is modeled as sub-blocks. The inverter and switching function are implemented as S-function builder block. The Sensorless scheme employs direct back emf based zero crossing detection technique. Results: The proposed model with Sensorless control technique with back emf zero crossing detection is tested in the BLDC Motor and the performance was evaluated. The simulated and experimental results show that the proposed modeling works quite well during starting and running conditions. Conclusion/Recommendation: The developed model consists of several independent sub-blocks, that can be used in the modeling of Permanent Magnet Sinusoidal Motor and induction motor. Hence the developed simulation model is a design tool to study the dynamic behavior of Sensorless Controlled Brushless DC Motor.
\end{abstract}

Key words: PMBLDC motor, simplified modeling, sensorless scheme operation, back emf zeroes cross Zero Cross Point (ZCP), Voltage Source Inverters (VSI)

\section{INTRODUCTION}

In the literature, there are several simulation models available for PMBLDC motor drives. They are either state space modeling or modeling based on d-q transformation, but there is no comprehensive model for the analysis of motor with Sensorless operation (Luk and Lee, 1994). The machine models are often transformed to a rotating reference frame to simplify and to improve the computational efficiency. But, this approach will not improve the computational efficiency because the d-q transformations are suitable only for machines with sinusoidal voltage as discussed. The PMBLDC motors are normally powered by conventional three phase inverter, controlled by the rotor position information obtained from hall sensors, resolvers or absolute position sensors. But these position sensors have numerous drawbacks like increase in cost, complexity in control, temperature sensitivity requiring special arrangements. These sensors reduce the system reliability and acceptability. Therefore, Sensorless techniques have become a subject of great interest in recent times. The Sensorless techniques in the literature are based on sensing the back emf, (Kaliappan et al., 2011) observer based and artificial intelligence based. An adaptive controller for PMBLDC Motor drive systems using Adaptive Network based fuzzy interference system was presented (Lee and Ehsani, 2003).

A PMBLDC motor operates in a two phase ON mode i.e. Two phases which produce maximum torque is excited leaving the third phase open. The back emf in open phase is sensed to determine the switching sequence of the inverter (Rao et al., 2008). The Sensorless control technique based on estimation of Zero Crossing Point (ZCP) of the back emf is widely used for low cost application (Shao, 2006). A simple Sensorless technique using back emf zero crossing is presented for PMBLDC motor (Kaliappan et al., 2011).

In this study a MATLAB/SIMULINK model of PMBLDC motor suitable for Sensorless operation is developed. Using this model, the dynamic behavior of the motor with the Sensorless technique is studied.

Modeling of pmbldc motor for Sensorless operation: In this modeling a three phase star connected BLDC motor with six step commutation is used for the analysis.

Corresponding Author: Kaliappan, E., Department of Electrical and Electronics Engineering, RMK Engineering College, Kavaraipettai, Chennai-601206, India 


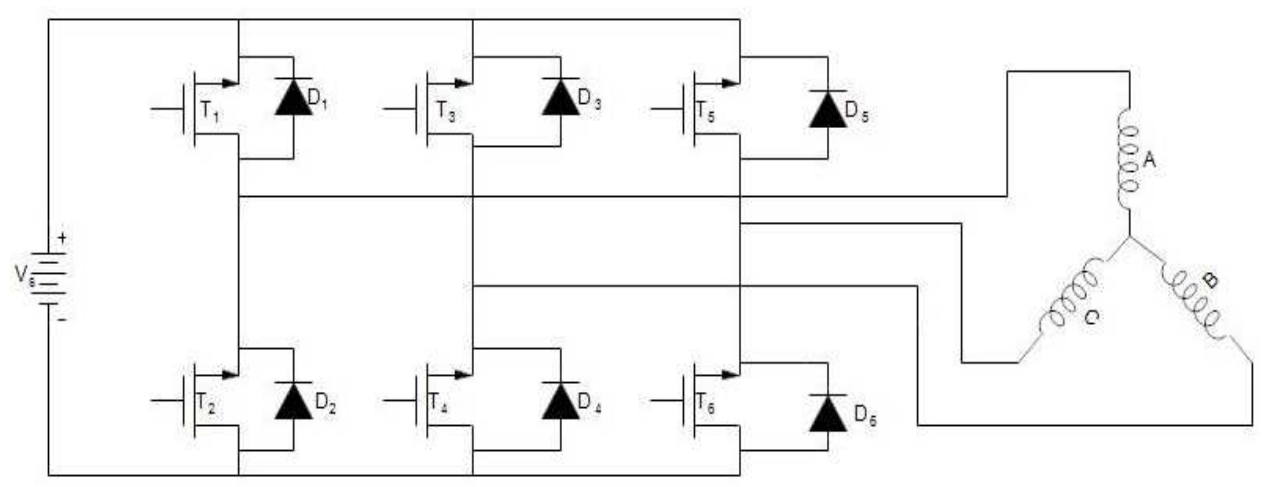

Fig. 1: Basic PMBLDC motor Drive scheme

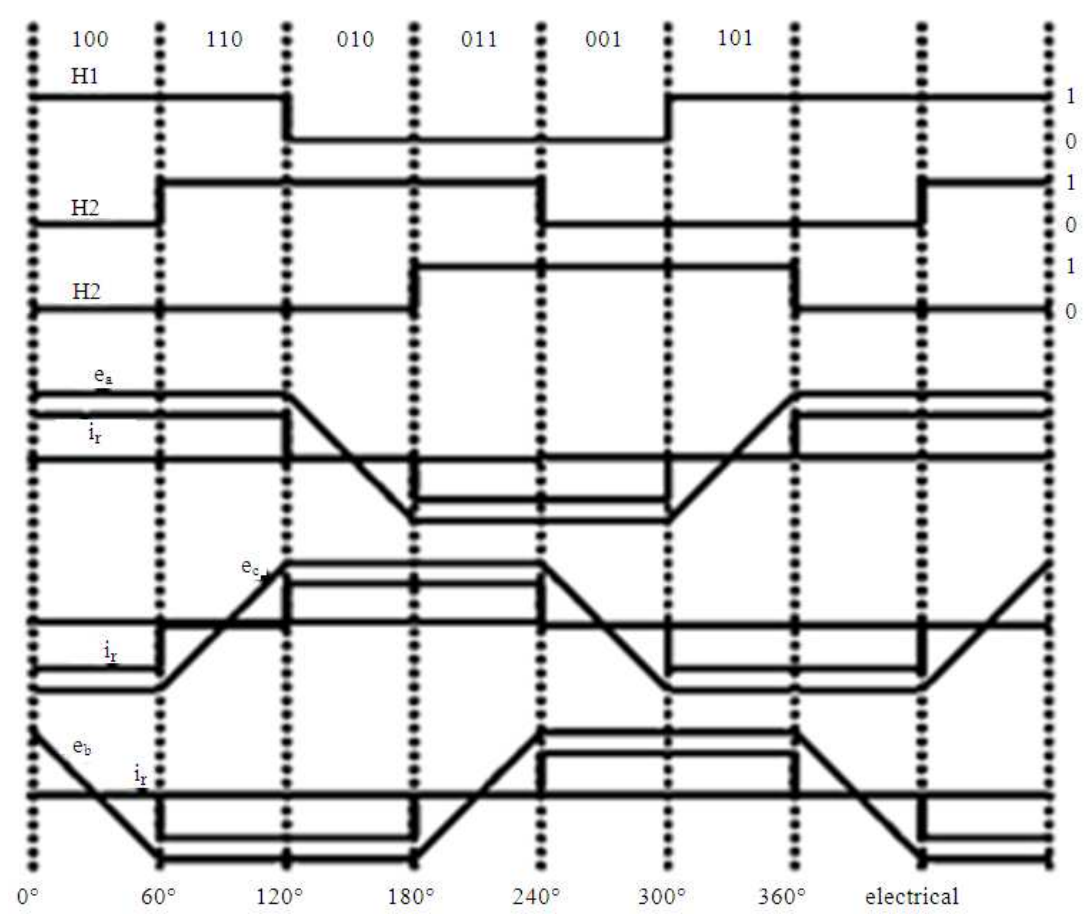

Fig. 2: Ideal current and back-emf waveform with hall the signals

Figure 1 shows the simplified BLDC motor drive scheme and Fig. 2 gives Ideal current and back-emf waveforms with hall signals. For 120 electrical degree conduction, commutation occurs at every $60^{\circ}$ based on the position information.

PMBLDC motor modeling: The equations involved in the modeling of PMBLDC motor shown in Fig. 1 are derived as Eq. 1-3:

$\mathrm{v}_{\mathrm{ab}}=\mathrm{R}\left(\mathrm{i}_{\mathrm{a}}-\mathrm{i}_{\mathrm{b}}\right)+\mathrm{L} \frac{\mathrm{d}}{\mathrm{dt}}\left(\mathrm{i}_{\mathrm{a}}-\mathrm{i}_{\mathrm{b}}\right)+\mathrm{e}_{\mathrm{a}}-\mathrm{e}_{\mathrm{b}}$

$$
\begin{aligned}
& v_{b c}=R\left(i_{b}-i_{c}\right)+L \frac{d}{d t}\left(i_{b}-i_{c}\right)+e_{b}-e_{c} \\
& v_{c a}=R\left(i_{c}-i_{a}\right)+L \frac{d}{d t}\left(i_{c}-i_{a}\right)+e_{c}-e_{a}
\end{aligned}
$$

Where:

$$
\begin{array}{ll}
\mathrm{R} & =\text { Per phase Stator resistance } \\
\mathrm{L} & =\text { Per phase Stator inductance } \\
\mathrm{i}_{\mathrm{a}}, \mathrm{i}_{\mathrm{b}}, \mathrm{i}_{\mathrm{c}} & =\text { Instantaneous stator phase currents } \\
\mathrm{v}_{\mathrm{ab}}, \mathrm{v}_{\mathrm{bc}} \text { and } \mathrm{v}_{\mathrm{ca}} & =\text { Instantaneous stator line voltages } \\
\mathrm{e}_{\mathrm{a}}, \mathrm{e}_{\mathrm{b}} \text { and } \mathrm{e}_{\mathrm{c}} & =\text { Instantaneous phase back-emfs }
\end{array}
$$


The relationship between the phase current is given by Eq. 4 :

$$
\mathrm{i}_{\mathrm{a}}+\mathrm{i}_{\mathrm{b}}+\mathrm{i}_{\mathrm{c}}=0
$$

The equation is rewritten as Eq. 5:

$$
\mathrm{i}_{\mathrm{c}}=-\left(\mathrm{i}_{\mathrm{a}}+\mathrm{i}_{\mathrm{b}}\right)
$$

Using Eq. 5 the line voltage Eq. 1 and 2 rewritten as Eq. 6 and 7:

$$
\begin{aligned}
& \mathrm{v}_{\mathrm{ab}}=\mathrm{R}\left(\mathrm{i}_{\mathrm{a}}-\mathrm{i}_{\mathrm{b}}\right)+\mathrm{L} \frac{\mathrm{d}}{\mathrm{dt}}\left(\mathrm{i}_{\mathrm{a}}-\mathrm{i}_{\mathrm{b}}\right)+\mathrm{e}_{\mathrm{a}}-\mathrm{e}_{\mathrm{b}} \\
& \mathrm{v}_{\mathrm{bc}}=\mathrm{R}\left(\mathrm{i}_{\mathrm{a}}+2 \mathrm{i}_{\mathrm{b}}\right)+\mathrm{L} \frac{\mathrm{d}}{\mathrm{dt}}\left(\mathrm{i}_{\mathrm{a}}+2 \mathrm{i}_{\mathrm{b}}\right)+\mathrm{e}_{\mathrm{b}}-\mathrm{e}_{\mathrm{c}}
\end{aligned}
$$

The back emf depends on the flux of the permanent magnet rotor and the speed of the rotor, it is expressed as Eq. 8:

$$
\left[\begin{array}{l}
e_{a} \\
e_{b} \\
e_{c}
\end{array}\right]=\frac{k_{e} w_{m}}{2}\left[\begin{array}{c}
F\left(\theta_{e}\right) \\
F\left(\theta_{e}-\frac{2 \Pi}{3}\right) \\
F\left(\theta_{e}-\frac{4 \Pi}{3}\right)
\end{array}\right]
$$
Eq. 9:

The generated electromagnetic torque is given by

$\mathrm{T}_{\mathrm{e}}=\left[\frac{\mathrm{K}_{\mathrm{e}}}{2} \mathrm{~F}\left(\theta_{\mathrm{e}}\right) \mathrm{i}_{\mathrm{a}}+\frac{\mathrm{K}_{\mathrm{e}}}{2} \mathrm{~F}\left(\theta_{\mathrm{e}}-\frac{2 \Pi}{3}\right) \mathrm{i}_{\mathrm{b}}+\frac{\mathrm{K}_{\mathrm{e}}}{2} \mathrm{~F}\left(\theta_{\mathrm{e}}-\frac{4 \Pi}{3}\right) \mathrm{i}_{\mathrm{c}}\right]$

Where:

$\theta_{\mathrm{e}}=\frac{\mathrm{p}}{2} \theta_{\mathrm{m}}$ Electrical angle, degrees

$\mathrm{w}_{\mathrm{m}}=$ Rotor speed, $\mathrm{rad} / \mathrm{sec}$

$\mathrm{k}_{\mathrm{e}}=$ Back-emf constant, volts $/ \mathrm{rad} / \mathrm{Sec}$

The dynamics of the motor and load is expressed as Eq. 10-14:

$$
\begin{aligned}
& T_{e}=K_{f} w_{m}+J \frac{d}{d t}\left(w_{m}\right)+T_{L} \\
& T_{e}-T_{L}=K_{f} w_{m}+J \frac{d}{d t}\left(w_{m}\right)
\end{aligned}
$$

$$
\mathrm{J} \frac{\mathrm{d}}{\mathrm{dt}}\left(\mathrm{w}_{\mathrm{m}}\right)=\mathrm{T}_{\mathrm{e}}-\mathrm{T}_{\mathrm{L}}-\mathrm{K}_{\mathrm{f}} \mathrm{w}_{\mathrm{m}}
$$

$$
\mathrm{w}_{\mathrm{m}}^{\prime}=-\frac{\mathrm{k}_{\mathrm{f}}}{\mathrm{J}} \mathrm{w}_{\mathrm{m}}+\frac{1}{\mathrm{~J}}\left[\mathrm{~T}_{\mathrm{e}}-\mathrm{T}_{\mathrm{L}}\right]
$$

$$
\theta_{\mathrm{m}}^{\prime}=\mathrm{w}_{\mathrm{m}}
$$

Where:

$$
\begin{aligned}
\mathrm{J} & =\text { Moment of inertia in } \mathrm{kg} / \mathrm{m}^{2} \\
\mathrm{k}_{f} & =\text { Friction constant in } \mathrm{Nm} / \mathrm{rad} / \mathrm{sec} \\
\mathrm{T}_{\mathrm{L}} & =\text { Load torque in } \mathrm{Nm} \\
\mathrm{k}_{\mathrm{t}} & =\text { Torque constant }
\end{aligned}
$$

Inverter modeling: Inverter and the switching sequence are modeled using $\mathrm{S}$ - functions. Table 1 shows the switching sequence, current direction and the position signals. The Zero crossing of the open phase voltage is sensed to determine the rotor position.

The triggering sequence generated by the $\mathrm{ZCP}$ of the back emf of the open phase is similar to the one produced by the hall sensors mounted on the machine. The operation of motor consists of six states. The expression of the voltages and current are given for the first state.

State 1: $\left(0-60^{\circ}\right)$.

Commutation period: The switches in phase A and phase B are energized and phase $\mathrm{c}$ is freewheeling through diode D5 Eq. 15:

$$
\begin{aligned}
& \text { For } \mathrm{i}_{\mathrm{c}} \neq 0 \\
& \mathrm{v}_{\mathrm{ab}}=\mathrm{v}_{\mathrm{s}} \\
& \mathrm{v}_{\mathrm{bc}}=0 \\
& \mathrm{v}_{\mathrm{ca}}=-\mathrm{v}_{\mathrm{s}}
\end{aligned}
$$

On period: Phases $\mathrm{A}$ and $\mathrm{B}$ carry current and $\mathrm{C}$ phase is open Eq. 16 and 17:

$$
\begin{aligned}
& \text { For } \mathrm{i}_{\mathrm{c}}=0 \\
& \mathrm{v}_{\mathrm{ab}}=\mathrm{v}_{\mathrm{s}} \\
& \mathrm{v}_{\mathrm{bc}}=\frac{1}{2}\left(-\mathrm{v}_{\mathrm{s}}+\mathrm{e}_{\mathrm{a}}+\mathrm{e}_{\mathrm{b}}-2 \mathrm{e}_{\mathrm{c}}\right) \\
& \mathrm{v}_{\mathrm{ca}}=\frac{1}{2}\left(-\mathrm{v}_{\mathrm{s}}-\mathrm{e}_{\mathrm{a}}-\mathrm{e}_{\mathrm{b}}+2 \mathrm{e}_{\mathrm{c}}\right) \\
& \text { For } \mathrm{i}_{\mathrm{c}} \neq 0 \\
& \mathrm{u}_{\mathrm{ab}}=\mathrm{v}_{\mathrm{ab}}-\left(\mathrm{e}_{\mathrm{a}}-\mathrm{e}_{\mathrm{b}}\right)=\mathrm{v}_{\mathrm{s}}-\mathrm{e}_{\mathrm{a}}+\mathrm{e}_{\mathrm{b}} \\
& \mathrm{u}_{\mathrm{bc}}=\mathrm{v}_{\mathrm{bc}}-\left(\mathrm{e}_{\mathrm{b}}-\mathrm{e}_{\mathrm{c}}\right)=-\mathrm{e}_{\mathrm{b}}+\mathrm{e}_{\mathrm{c}} \\
& \mathrm{u}_{\mathrm{ca}}=\mathrm{v}_{\mathrm{ca}}-\left(\mathrm{e}_{\mathrm{c}}-\mathrm{e}_{\mathrm{a}}\right)=-\mathrm{v}_{\mathrm{s}}-\mathrm{e}_{\mathrm{c}}+\mathrm{e}_{\mathrm{a}}
\end{aligned}
$$


where, $\mathrm{u}_{\mathrm{ab}}, \mathrm{u}_{\mathrm{ac}}$ and $\mathrm{u}_{\mathrm{ca}}$ are the voltage drops across the impedance consisting of resistance and inductance of the phases.

Simulation results: The specifications of the BLDC motor used for the simulation are given in Table 2 . Equations 1-14 have been used to develop a simulation model using an $\mathrm{S}$ - function in MATLAB. Figure 3 shows the complete simulation model of the PMBLDC motor drive consisting of three blocks namely: switching sequence block, inverter block and BLDC motor block.

The BLDC motor block as labeled in the Fig. 4 represents the Eq. 1-8. Figure 6 represents the BLDC motor's voltage and current equations Eq. 5 and 6 which take the dc voltage $\mathrm{v}_{\mathrm{ab}}, \mathrm{v}_{\mathrm{bc}}$ as inputs and gives the phase current $i_{s}$ as an output.
Table 1: Switching sequence

\begin{tabular}{|c|c|c|c|c|c|c|c|c|c|}
\hline \multirow{2}{*}{$\begin{array}{l}\text { Switching } \\
\text { interval } \\
\text { Degree }\end{array}$} & \multirow{2}{*}{$\begin{array}{l}\text { Sequence } \\
\text { number }\end{array}$} & \multicolumn{3}{|c|}{ Position sensor } & \multirow{2}{*}{\multicolumn{2}{|c|}{$\begin{array}{l}\text { Switch } \\
\text { closed }\end{array}$}} & \multicolumn{3}{|c|}{ Phase current } \\
\hline & & H1 & $\mathrm{H} 2$ & $\mathrm{H} 3$ & & & A & B & $\mathrm{C}$ \\
\hline$(0-60)$ & 0 & 1 & 0 & 0 & T1 & T4 & & & Off \\
\hline & 1 & 1 & 1 & 0 & 1 & T6 & & & -Ic \\
\hline & & 0 & 1 & 0 & 1 & T6 & & & -Ic \\
\hline & 3 & 0 & 1 & 1 & T3 & $\mathrm{T} 2$ & a & $+\mathrm{Ib}$ & Off \\
\hline $40-300)$ & 4 & 0 & 0 & 1 & T5 & $\mathrm{T} 2$ & -Ia & off & $+\mathrm{Ic}$ \\
\hline $300-360)$ & 5 & 1 & 0 & 1 & T5 & $\mathrm{T} 4$ & off & $-\mathrm{Ib}$ & $+\mathrm{Ic}$ \\
\hline
\end{tabular}

Table 2: Motor parameters

\begin{tabular}{ll}
\hline Motor parameters & Values \\
\hline Per phase resistance $(\mathrm{R})$ & $0.6 \mathrm{ohm}$ \\
Per phase Inductance $(\mathrm{L})$ & $0.42 \mathrm{mH}$ \\
Moment of inertia $(\mathrm{J})$ & $0.0002 \mathrm{Kg}-\mathrm{m}^{2}$ \\
Back Emf Constant $(\mathrm{Kb})$ & $0.1 \mathrm{~V} / \mathrm{rad} / \mathrm{sec}$ \\
Torque Constant $(\mathrm{Kt})$ & $0.1 \mathrm{Nm} / \mathrm{A}$ \\
Number of poles & 8 \\
\hline
\end{tabular}

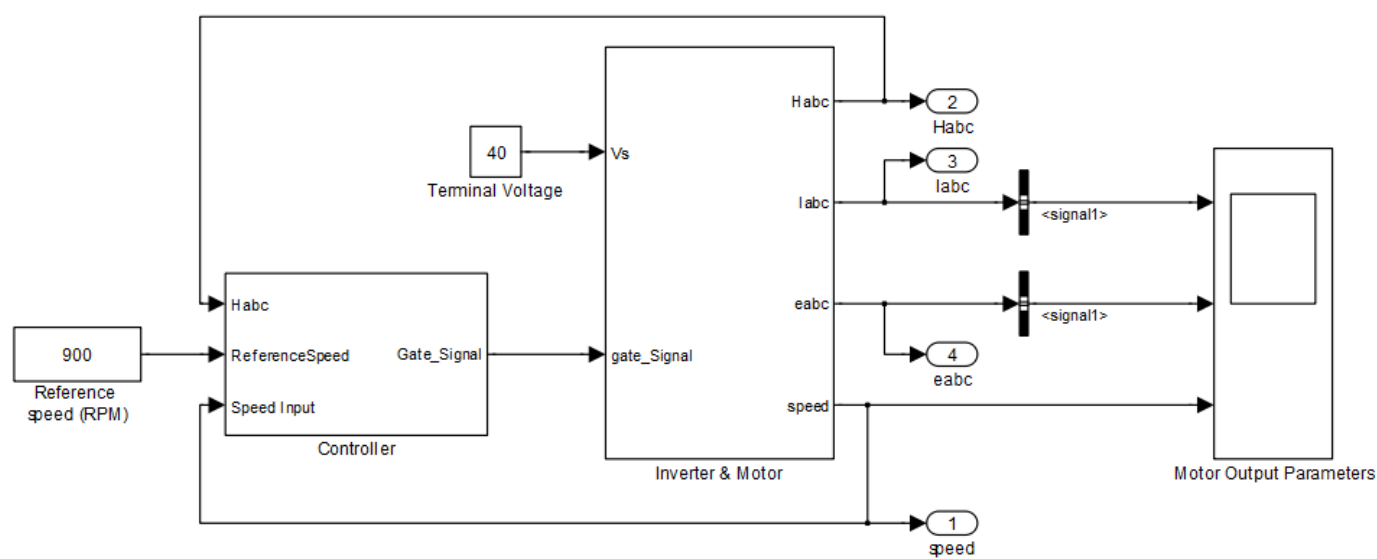

Fig. 3: Complete simulation model of the PMBLDC motor drive

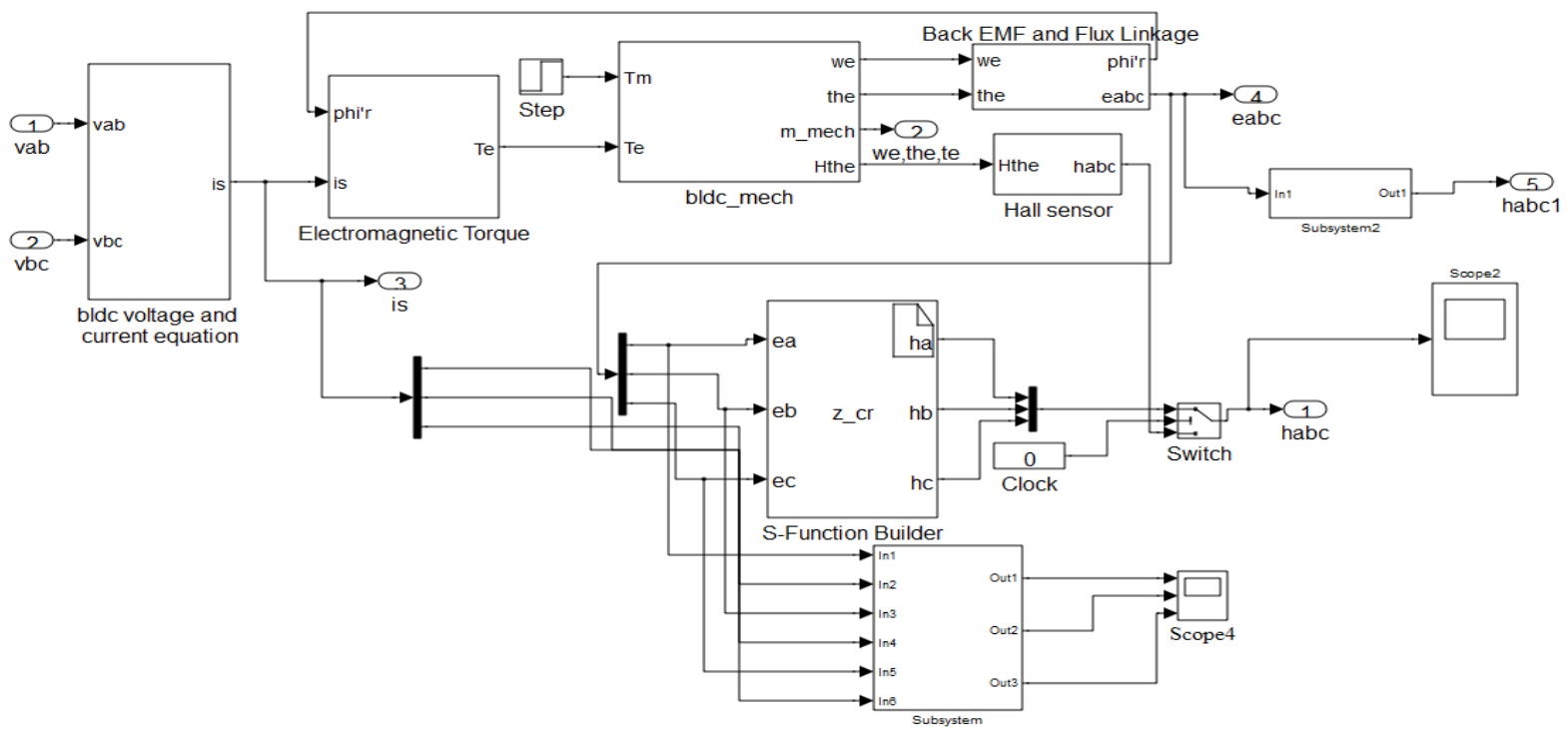

Fig. 4: Sub-blocks of BLDC motor model with back emf zero cross detection 


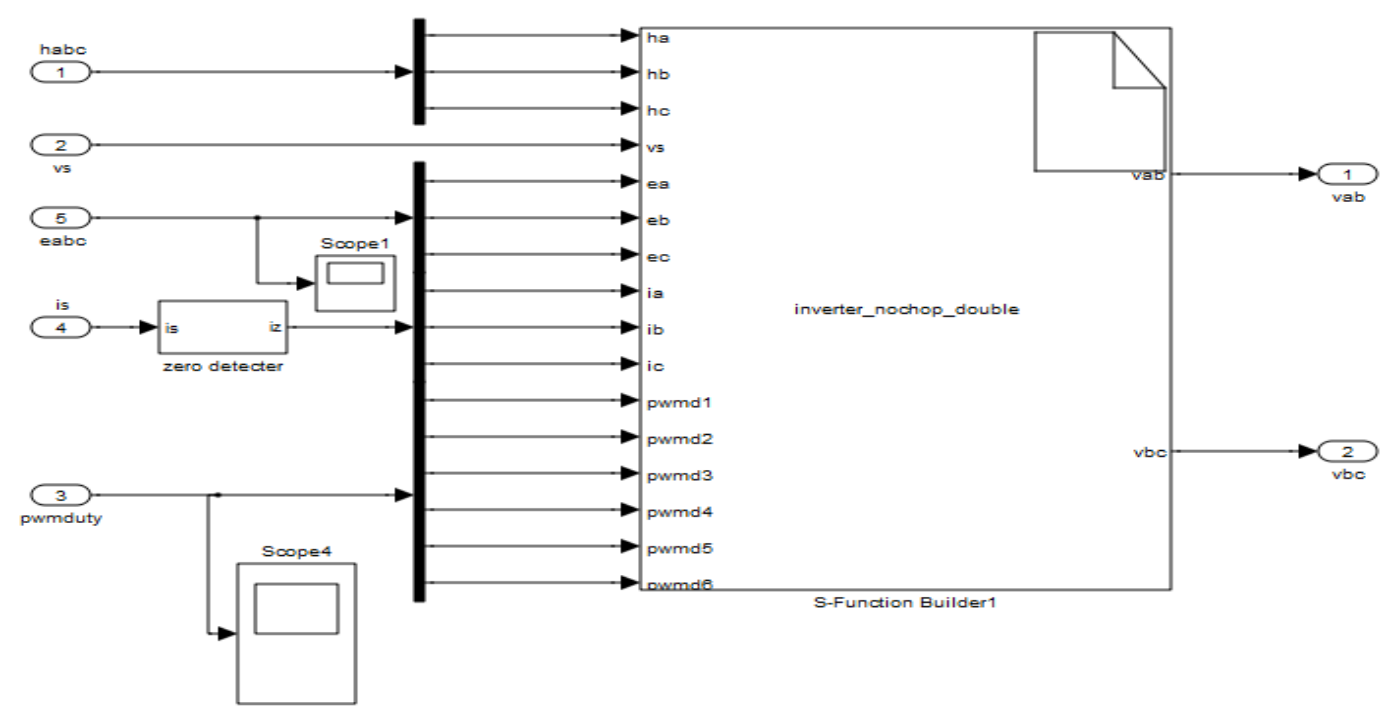

Fig. 5: The inverter S-function builder

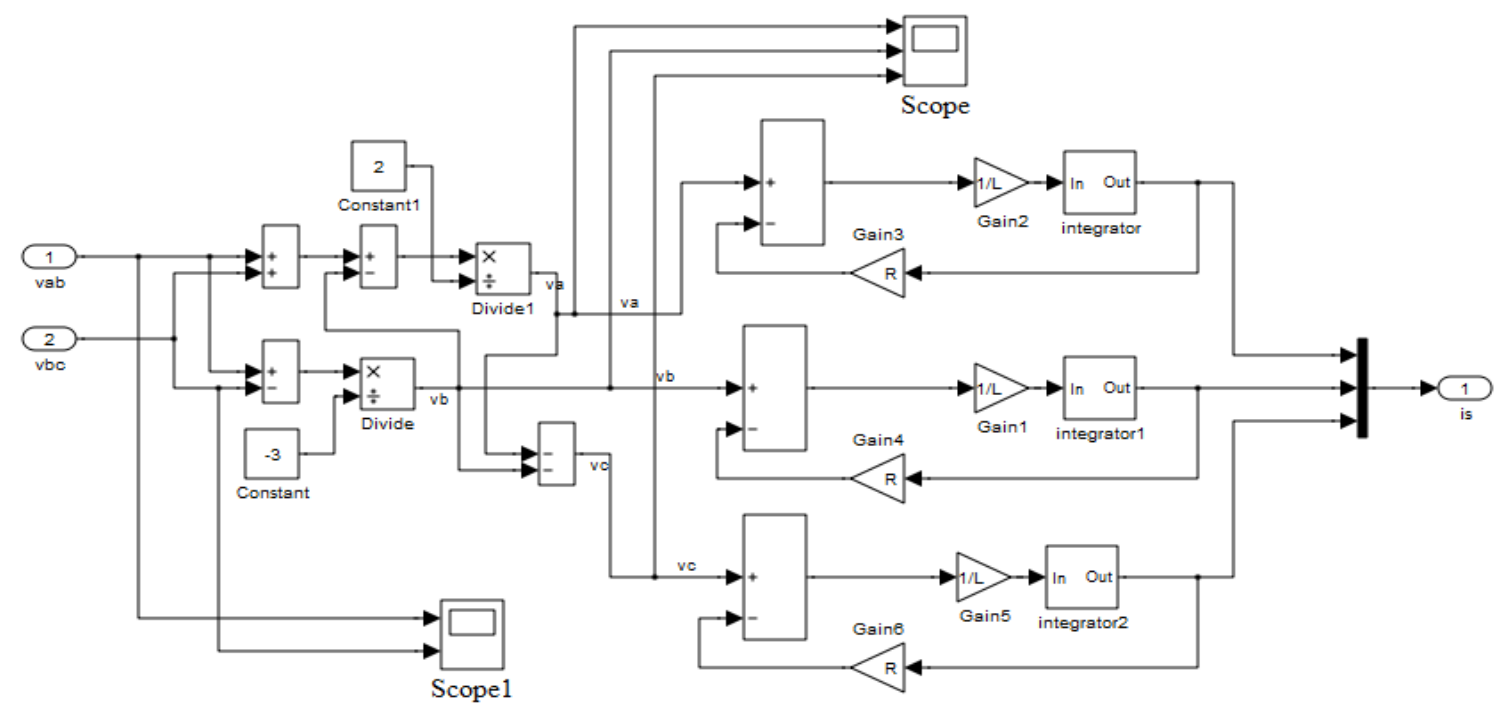

Fig. 6: BLDC voltage and current equation block

The Electromagnetic torque block is implemented using Eq. 9, where Voltage and Current are the inputs along with the flux linkage and produces the electromagnetic torque $\left(\mathrm{T}_{\mathrm{e}}\right)$ as the output. Equation 10-14 are modeled as the mechanical block which takes the electromagnetic torque $\left(\mathrm{T}_{\mathrm{e}}\right)$ and the load torque $\left(\mathrm{T}_{\mathrm{L}}\right)$ as input parameters and gives speed and position as output response. Figure 8 shows the back emf zero crossing detection block. Phase current and back emf are input to this block. The subsystem of the zero cross detection circuit gives the Sensorless position information. Figure 5 and 7 shows the inverter and switching logic functional block. The DC voltage and sequence of the control are the input to this block. The firing signal includes a PWM option for any 60 degree intervals. The output voltage of the inverter depends on the DC source voltage, rotor position, phase current and also the value of the back emf. When a switch in a phase is turned off, the outgoing phase current freewheels through the diode where as the incoming phase current increases from Zero to full load value. The position of the rotor decides the incoming and outgoing phases. 
Am. J. Applied Sci., 9 (7): 1046-1054, 2012

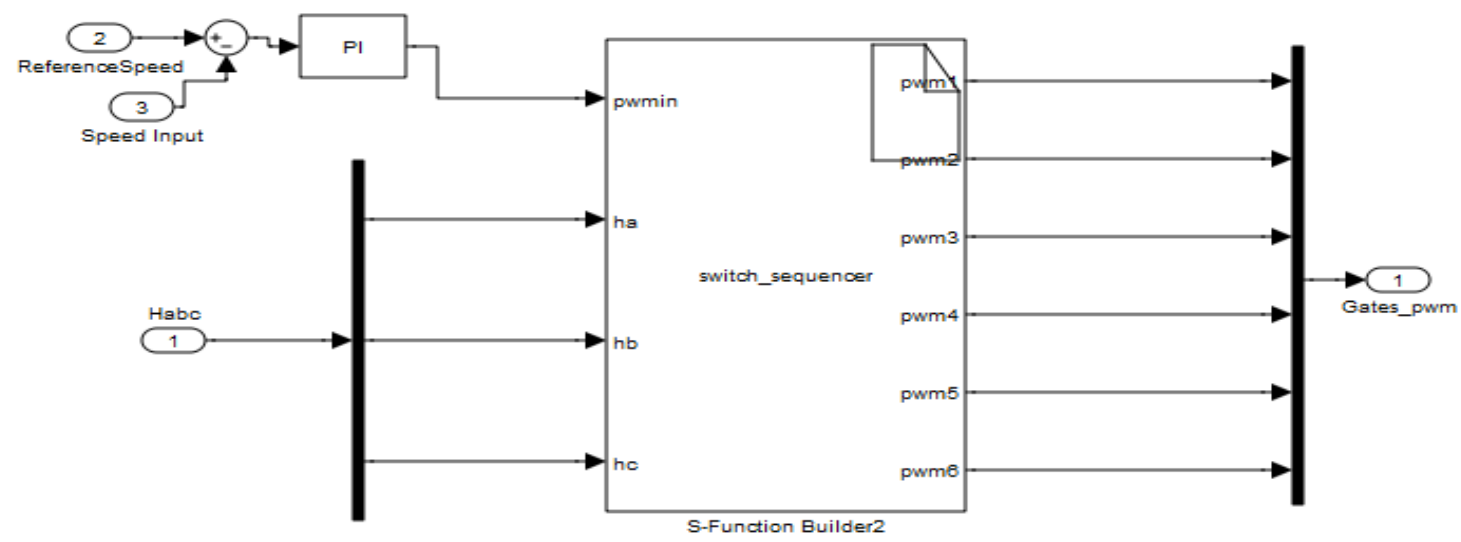

Fig. 7: Generating the switching sequence

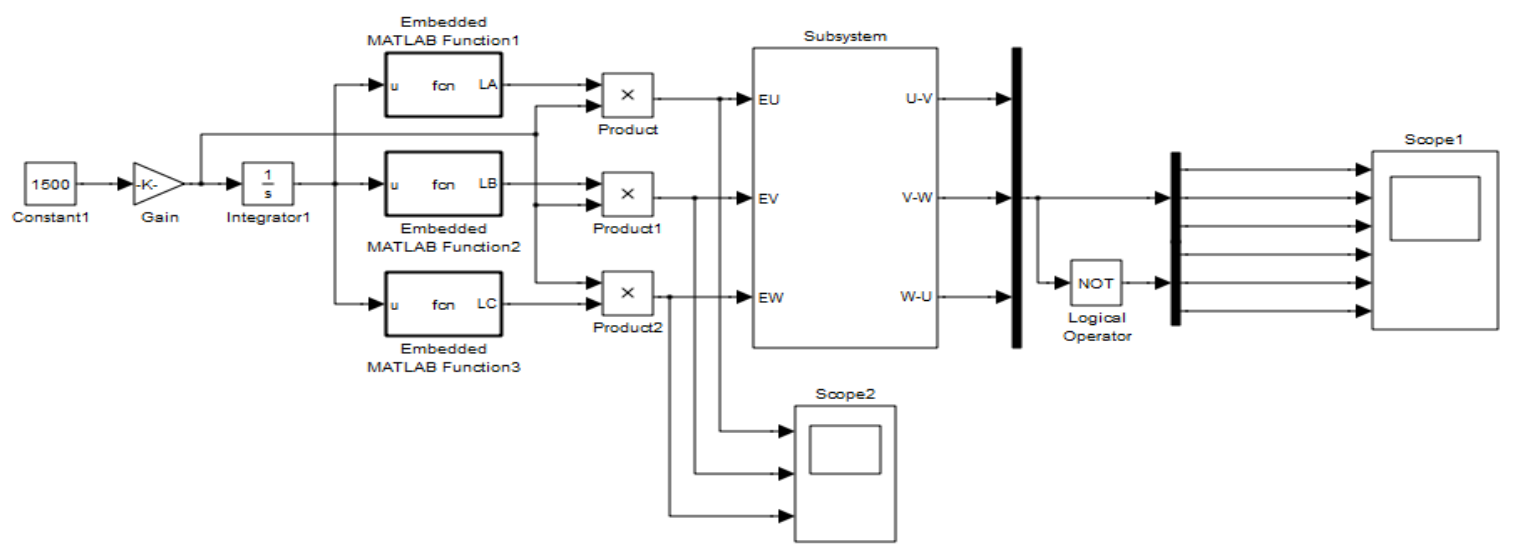

Fig. 8: Zero crossing detection block

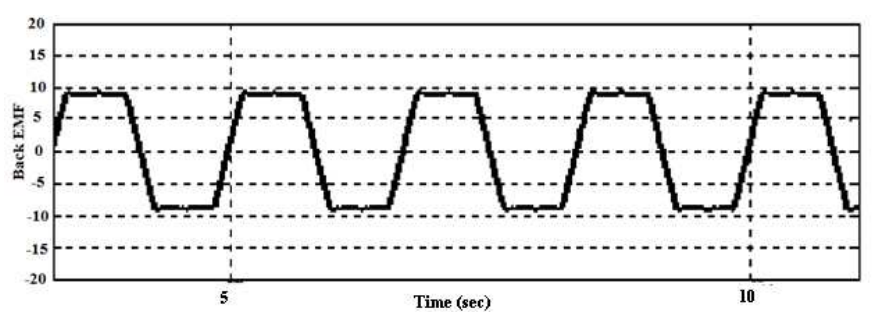

(a)

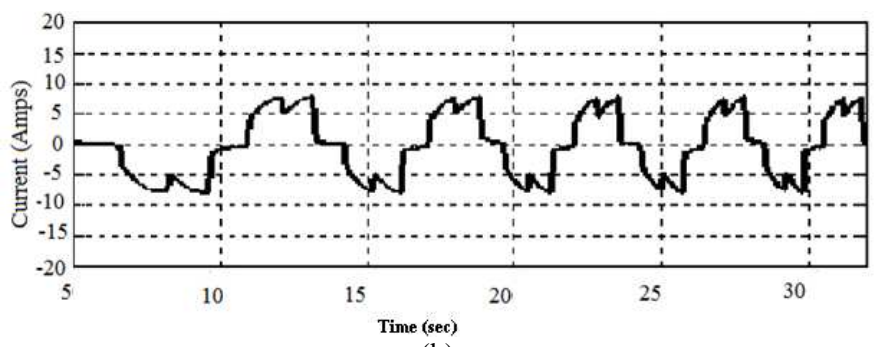

(b)

Fig. 9: Generated Back emf waveform and Phase current waveform from the rotor position 


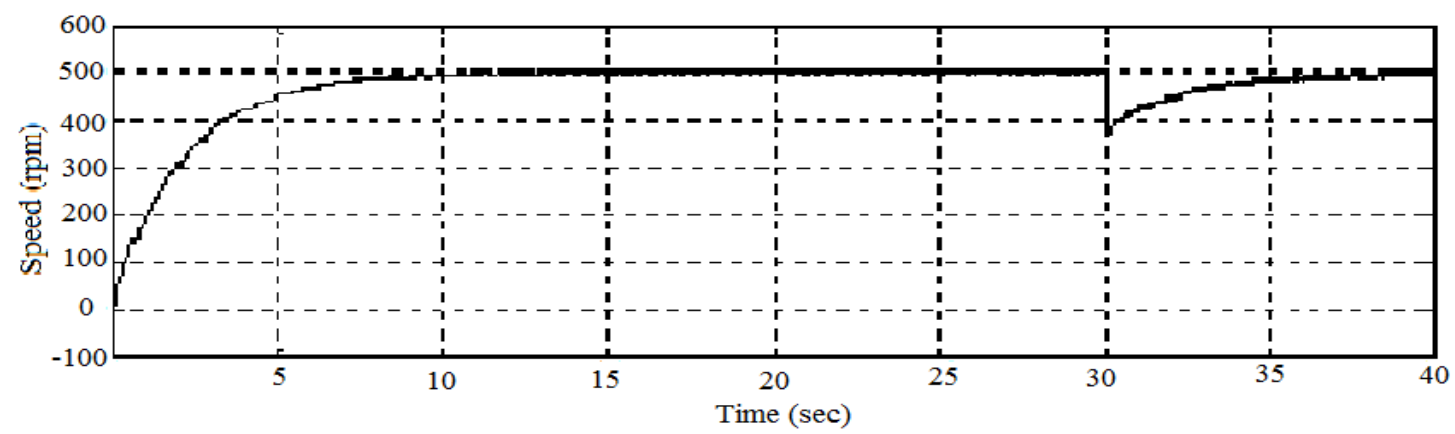

Fig. 10: Speed waveform in rpm

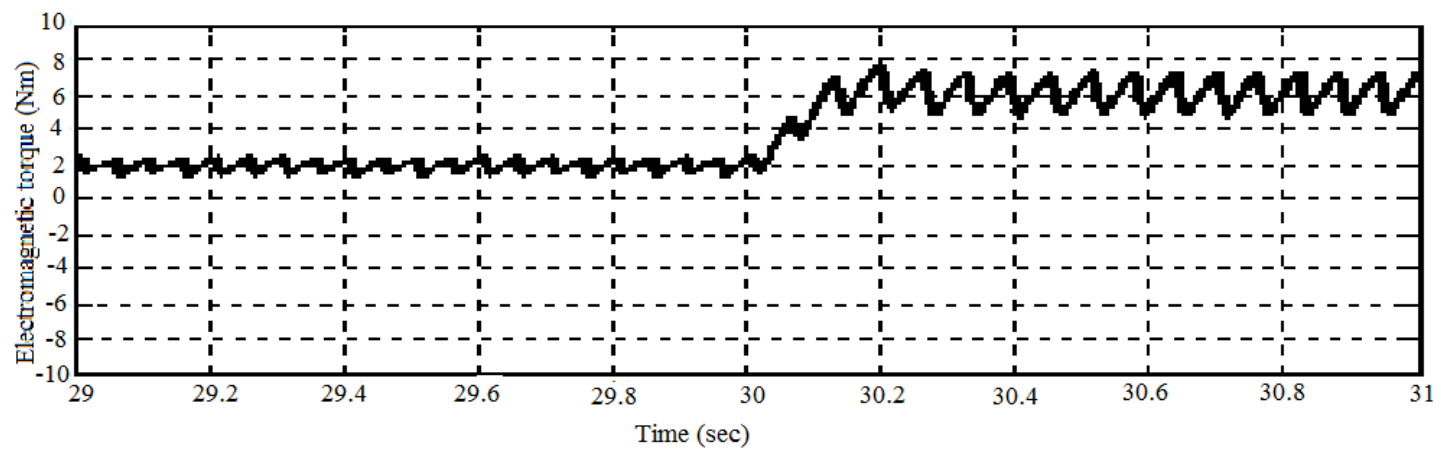

Fig. 11: Electromagnetic torque waveform (zoomed view)

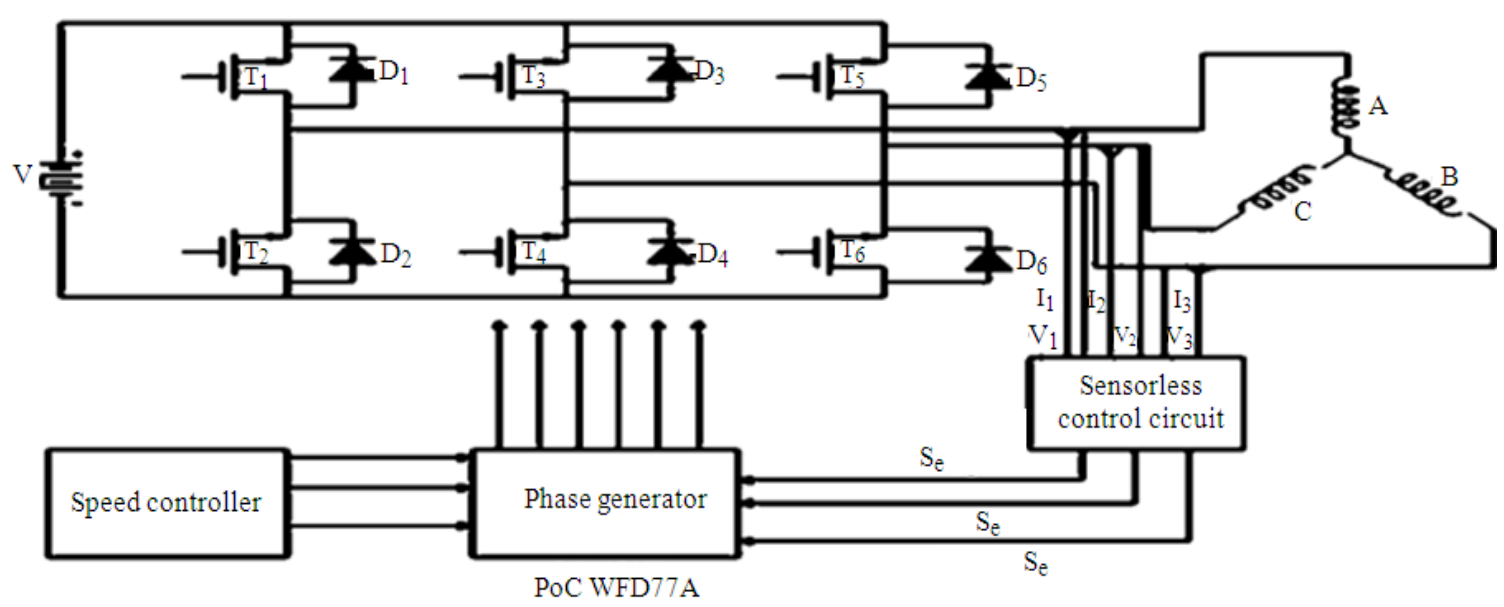

Fig. 12: Block diagram of the experimental setup

Figure 9 shows the back emf and the phase current waveforms obtained from the simulated model. The developed model is simulated for a period of 1 second.

Figure 10 and 11 shows the speed and electromagnetic torque waveforms captured when a load of $0.5 \mathrm{Nm}$ is applied at $0.4 \mathrm{sec}$.
Experimental results: The experimental setup used for the validation of the proposed modeling of BLDC motor for Sensorless operation is given in Fig. 12. It consists of C0851F310 microcontroller, a 3 phase MOSFET, voltage divider circuit, current amplifier, speed and current controller and three dual gate drivers. 


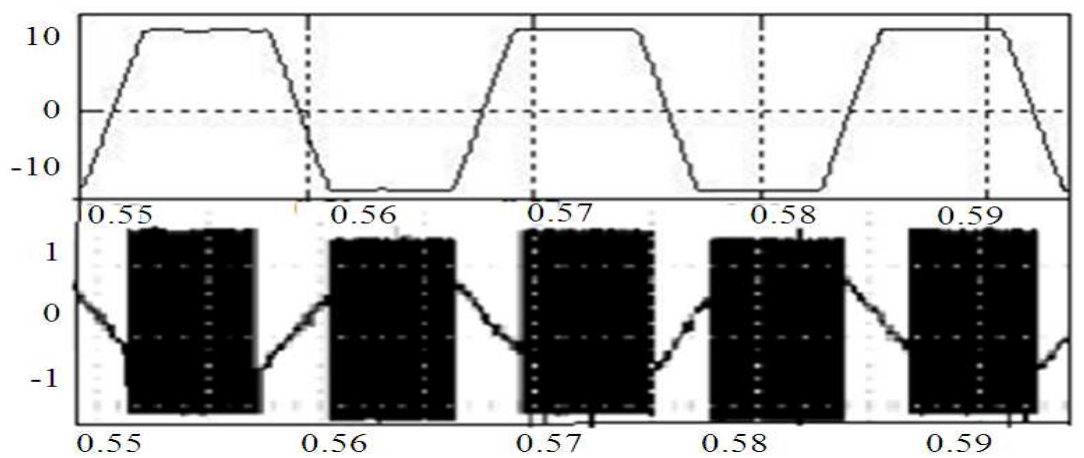

Fig. 13: Back emf waveform with the Switching Function (Experimental)

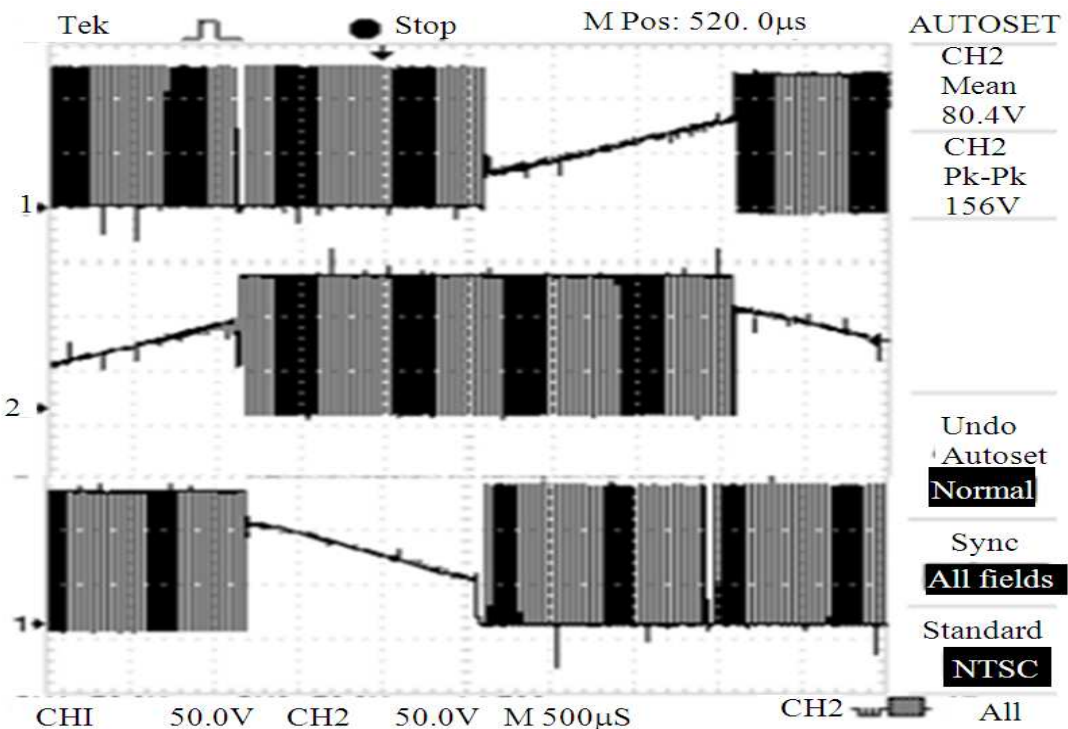

Fig. 14: Switching Function and voltage waveforms of the Three Phases

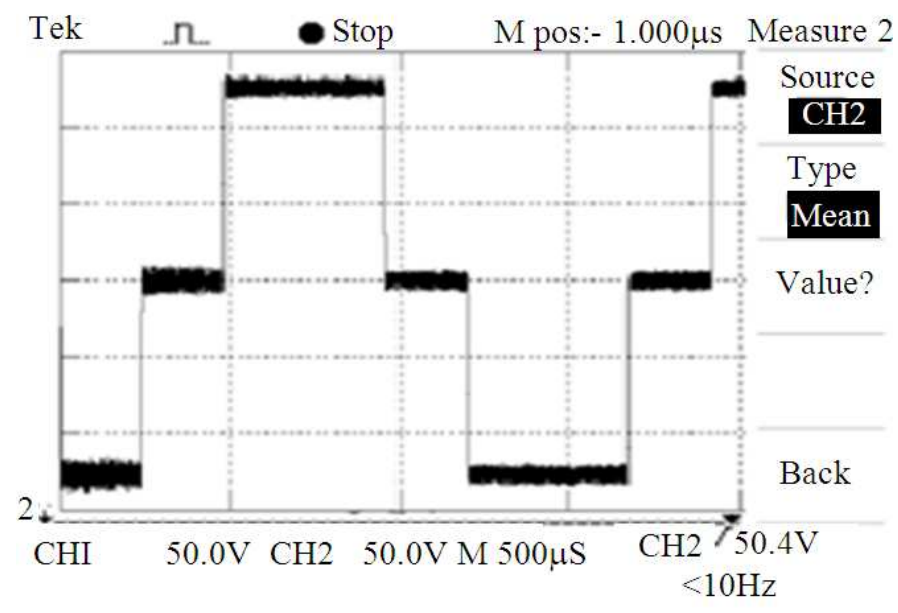

Fig. 15: Measured phase current waveform 1053 
Three simple resistive divider circuits are connected to the three output phases with the bottom resistor consists of a capacitor in it acting as an RC filter circuit. Motors supply voltage is sensed by connecting a resistive divider circuit across the terminal. Figure 13 shows the back emf waveform with switching functions measured from the experimental setup. Figure 14 and 15 show the expanded view measured switching functions of three phases according to conducting modes and phase current waveform.

\section{CONCLUSION}

This study presents a simplified modeling, analysis and simulation of PMBLDC motors. In the presented work, back emf zero crossing detection circuit is used for estimating the rotor position. The voltage and current waveform of the machine is monitored and compared with those obtained from the hall sensors. The results of the Sensorless operation matched very closely with those results obtained with the hall sensors. This clearly demonstrates that the proposed model for based Sensorless control can replace the hall sensor in the PMBLDC drive. This model can be easily extended for the other Sensorless control techniques with a minor change in the model.

\section{REFERENCES}

Kaliappan, E. and C. Chellamuthu, 2011. A simple Sensorless control technique for PMBLDC motor using back EMF zero crossing. Eur. J. Sci. Res., 60: 347-360.
Kaliappan, E., C. Chellamuthu and B. Balashankar, 2011. A Simple and improved Sensorless control technique for PMBLDC motor. Commun. Intel. Inform. Sci., 250: 433-435. DOI: 10.1007/978-3642-25734-6_69

Lee, B.K. and M. Ehsani, 2003. Advanced simulation model for brushless DC Motor drives. Elect. Power Comp. Syst., 31: 841-868. DOI: 10.1080/15325000390227191

Luk, P.C.K. and C.K Lee, 1994. Efficient Modeling of Brushless DC motor drives. Indus. Elect Control Instrumentation.

Rao, K.S.R., Nagadevan and S. Taib, 2008. Sensorless control of a BLDC motor with back EMF detection method using DSPIC. Proceedings of the IEEE 2nd International Power and Energy Conference, Dec. 1-3, IEEE Xplore Press, Johor Bahru, pp: 243-248. DOI: 10.1109/PECON.2008.4762477

Shao, J., 2006. An improved microcontroller-based Sensorless brushless DC (BLDC) motor drive for automotive applications. IEEE Trans. Indus. Appli., $\quad 42$ : 1216-1221. DOI: 10.1109/TIA.2006.880888 